\title{
Thermus igniterrae sp. nov. and Thermus antranikianii sp. nov., two new species from Iceland
}

\author{
Ana Paula Chung, ${ }^{1}$ Fred A. Rainey, ${ }^{2,3}$ Margarida Valente, ${ }^{1}$ \\ M. Fernanda Nobre ${ }^{4}$ and Milton S. da Costa ${ }^{1}$
}
1 Departamento de Bioquímica and Centro de Neurociências de Coimbra, Universidade de Coimbra, 3000 Coimbra, Portugal
2 Department of Biological Sciences, Louisiana State University, Baton Rouge, LA 70803, USA
3 DSMZ - Deutsche Sammlung von Mikroorganismen und Zellkulturen, Braunschweig, D-38124, Germany
4 Departamento de Zoologia, Universidade de Coimbra, 3004-517 Coimbra, Portugal

\author{
Author for correspondence: Milton S. da Costa. Tel: +351 239 824024. Fax: + 351239826798 \\ e-mail: milton@cygnus.ci.uc.pt
}

\begin{abstract}
Several yellow-pigmented isolates, with optimum growth temperatures of about $65-70{ }^{\circ} \mathrm{C}$, were recovered from hot springs in Iceland. Phylogenetic analysis of the 16S rDNA and DNA-DNA reassociation values showed that these organisms represented two new species of the genus Thermus. Strains RF-4 and HN1-8 had maximum temperatures for growth below $80^{\circ} \mathrm{C}$, while strains HN3-7 and HN2-7, unlike all other strains of the species of the genus Thermus except those belonging to Thermus thermophilus, grew at $80{ }^{\circ} \mathrm{C}$. The new isolates from Iceland could not be distinguished easily from each other or from other strains of the species of the genus Thermus by biochemical characteristics; however, strains RF-4 ${ }^{\top}$ and HN1-8 assimilated ribitol, a characteristic which was not detected in any of the other strains examined. Moreover, the species represented by strains RF-4 ${ }^{\top}$ and HN1-8 and the species represented by strains HN3-7 and HN2-7 could be distinguished clearly from the other species of Thermus by their fatty acid composition. Strains RF-4 ${ }^{\top}$ and HN1-8 have the highest combined levels of iso-15:0 and iso-17:0 and the lowest levels of iso-16:0 of any of the strains of the species of Thermus, while strains HN3-7 ${ }^{\top}$ and HN2-7 are characterized by a very low iso-15:0/iso-17:0 ratio. On the basis of the phylogenetic analysis, DNA-DNA reassociation values, physiological and biochemical characteristics and fatty acid composition, the name Thermus igniterrae sp. nov. is proposed for the species represented by strains RF-4 ${ }^{\top}$ and $\mathrm{HN} 1-8$ and the name Thermus antranikianii sp. nov. is proposed for the species represented by strains HN3-7' and HN2-7.
\end{abstract}

Keywords: Thermus igniterrae, Thermus antranikianii, Bacteria, thermophiles

\section{INTRODUCTION}

Strains of the species of the genus Thermus have been isolated from numerous hydrothermal areas throughout the world with water temperatures higher than about $55^{\circ} \mathrm{C}$ and $\mathrm{pH}$ ranging from neutral to alkaline (Kristjansson \& Alfredsson, 1983; Williams \& da Costa, 1992). Many strains also originate from artificial thermal environments (Brock \& Boylen, 1969; Degryse et al., 1978; Kristjansson et al., 1994) and some strains have also been isolated from abyssal geothermal sites (Marteinsson et al., 1995). Six species of the genus Thermus have been validly described.

The EMBL accession numbers for the Thermus sp. 165 rDNA sequences determined in this study are $\mathrm{Y} 18406-\mathrm{Y} 18416$.
These are Thermus aquaticus (Brock \& Freeze, 1969), Thermus thermophilus (Oshima \& Imahori, 1974; Manaia et al., 1994; Williams et al., 1995), Thermus filiformis (Hudson et al., 1987), Thermus scotoductus (Kristjansson et al., 1994), Thermus brockianus (Williams et al., 1995) and Thermus oshimai (Williams et al., 1996).

Elucidation of the taxonomy of the genus Thermus has been hindered for several reasons: the number of strains used to describe some species is small and is sometimes limited to one isolate and the number of phenotypic characteristics used to describe the species is, in many cases, also small. Moreover, the large phenotypic diversity within closely related isolates, which presumably belong to the same species, inevitably leads to the description of species without 
representative phenotypes or characteristics that can be used to distinguish the species from one another. For example, T. filiformis was described on the basis of one naturally filamentous strain that contains large relative proportions of anteiso fatty acids (Hudson et al., 1987; Ferraz et al., 1994). However, other strains from New Zealand assigned to this species on the basis of DNA-DNA reassociation values are not filamentous and contain large proportions of iso fatty acids (Georganta et al., 1993; Ferraz et al., 1994). The species $T$. aquaticus and $T$. brockianus, originally recovered from Yellowstone National Park, can be distinguished easily from each other (Brock \& Freeze, 1969; Munster et al., 1986; Williams et al., 1995). However, when biochemical and physiological characteristics of these organisms are compared with those of other species and with strains of $T$. brockianus from other geothermal areas, the distinctiveness of these species breaks down, even though there is no doubt that these two species constitute distinct genospecies. On the other hand, two species of the genus Thermus have characteristics that distinguish them from other species of the genus. T. aquaticus can be distinguished from all other species of the genus Thermus by its fatty acid composition since, at present, it is the only species that contains moderate levels of 3-hydroxy iso fatty acids. However, all known isolates originate from Yellowstone National Park and may be very closely related (Nobre et al., 1996). Strains of T. thermophilus can also be distinguished from all other species of the genus Thermus by their ability to grow at temperatures above $80{ }^{\circ} \mathrm{C}$ and in medium containing $2-3 \% \mathrm{NaCl}$ (Manaia \& da Costa, 1991; Manaia et al., 1994).

In this paper, we report the description of two new species of the genus Thermus isolated from hot springs in Iceland. At the phenotypic level, the two new species can only be distinguished clearly from other species on the basis of their fatty acid composition and by the ability of the strains of one of the new species to grow at $80^{\circ} \mathrm{C}$. However, at the genetic level, DNA-DNA reassociation values and phylogenetic analyses of the $16 \mathrm{~S}$ rRNA gene sequences show that the new isolates belong to two species that have not been described previously. On the basis of the results presented in this study, we propose the names Thermus igniterrae sp. nov. for strains $\mathrm{RF}-4^{\mathrm{T}}$ and HN1-8 and Thermus antranikianii sp. nov. for strains $\mathrm{HN} 3-7^{\mathrm{T}}$ and $\mathrm{HN} 2-7$.

\section{METHODS}

Isolation and bacterial strains. Strains $\mathrm{RF}-4^{\mathrm{T}}, \mathrm{HN} 1-8, \mathrm{GE}-2$, HN3-7 ${ }^{\mathrm{T}}$, HN2-7, HN2-3, HN3-10 and HE-5 were isolated from hot springs within several geothermal areas in eastern and south-eastern Iceland. Water samples were transported without temperature control and filtered through membrane filters (Gelman type GN-6; pore size $0.45 \mu \mathrm{m}$, diameter 47 $\mathrm{mm}$ ), which were placed on the surface of Thermus agar plates (Williams \& da Costa, 1992). These preparations were wrapped in plastic bags and incubated at $70{ }^{\circ} \mathrm{C}$ for up to $7 \mathrm{~d}$. Cultures were purified by subculturing and were preserved at $-80{ }^{\circ} \mathrm{C}$ in Thermus medium containing $15 \%$ glycerol.
Several strains of the species of the genus Thermus were used for comparative purposes and their sources are listed in Table 1. T. scotoductus strain X-1 (ATCC 27978) occurs as two colony variants that differ in their polar lipid composition (Tenreiro et al., 1995; Wait et al., 1997). Colony type $t 1$ has the usual polar lipid composition of strains of the genus Thermus and was used here for comparative purposes.

Morphological, biochemical and tolerance characteristics. Cell morphology and motility were examined by phasecontrast microscopy during the exponential growth phase in Thermus medium. Cell dimensions were determined with an ocular micrometer calibrated with a stage micrometer. Unless otherwise stated, all biochemical and tolerance tests were performed as described previously (Santos et al., 1989; Manaia \& da Costa, 1991) in Thermus liquid medium or on Thermus agar, incubated at $70{ }^{\circ} \mathrm{C}$ for up $5 \mathrm{~d}$. Catalase activity was determined by the formation of bubbles with a $3 \%$ hydrogen peroxide solution and oxidase activity was determined by the oxidation of $1 \%$ aqueous tetramethyl $p$ phenylenediamine on filter paper at room temperature. The growth temperature ranges of strains $\mathrm{RF}-4^{\mathrm{T}}$ and $\mathrm{HN} 3-7^{\mathrm{T}}$ and the type strains of T. brockianus and T. scotoductus were examined by measuring the turbidity $\left(\mathrm{OD}_{610}\right)$ of cultures incubated in $300 \mathrm{ml}$ metal-capped Erlenmeyer flasks containing $100 \mathrm{ml}$ Thermus medium in a reciprocal water-bath shaker. Growth of all strains was also assessed in $20 \mathrm{ml}$ metal-capped tubes containing $5 \mathrm{ml}$ Thermus medium placed in water-bath incubators at 78,80 and $82{ }^{\circ} \mathrm{C}$ for $5 \mathrm{~d}$. The $\mathrm{pH}$ range for growth was examined at $70{ }^{\circ} \mathrm{C}$ in the same medium by using $30 \mathrm{mM}$ MES for $\mathrm{pH}$ values between $5 \cdot 0$ and $6 \cdot 5,30 \mathrm{mM}$ Tris for $\mathrm{pH}$ values between $7 \cdot 0$ and 8.5 and $30 \mathrm{mM}$ CAPSO for $\mathrm{pH}$ values between $9 \cdot 0$ and $10 \cdot 5$; the $\mathrm{pH}$ of each buffer was adjusted with $\mathrm{HCl}$ or $\mathrm{NaOH}$. The $\mathrm{pH}$ values were determined at room temperature. Control media containing each buffer adjusted to $\mathrm{pH} 8 \cdot 2$ were used to assess possible inhibitory effects of the buffering agents.

Single-carbon-source assimilation tests were performed in a minimal medium composed of Thermus basal salts with yeast extract $\left(0 \cdot 1 \mathrm{~g} \mathrm{l}^{-1}\right)$ and without nitrate, to which filtersterilized ammonium sulphate $\left(0.5 \mathrm{~g} \mathrm{l}^{-1}\right)$ and the carbon sources $\left(2 \cdot 0 \mathrm{~g}^{-1}\right)$ were added. Growth was examined by measuring the turbidity of cultures incubated at $70^{\circ} \mathrm{C}$ in $20 \mathrm{ml}$ screw-capped tubes containing $10 \mathrm{ml}$ medium after $5 \mathrm{~d}$ growth. Positive and negative control cultures were grown in Thermus medium and in minimal medium without a carbon source, respectively.

Polar lipid and fatty acid composition. The cultures used for polar lipid analysis were grown in 11 Erlenmeyer flasks containing $200 \mathrm{ml}$ Thermus medium at $70^{\circ} \mathrm{C}$ in a reciprocal water-bath shaker until the exponential phase of growth. Harvesting of the cultures and the extraction of lipids was performed as described previously (Prado et al., 1988; Donato et al., 1990). The individual polar lipids were separated by one-dimensional TLC on silica gel G plates (Merck; $0.25 \mathrm{~mm}$ thick) with a solvent system consisting of chloroform:methanol:acetic acid:water $(80: 12: 15: 4$ by vol.).

Cultures for fatty acid analysis were grown on Thermus medium plates in sealed plastic bags submerged in a water bath at $70^{\circ} \mathrm{C}$ for $24 \mathrm{~h}$. Fatty acid methyl esters were obtained from fresh wet biomass by saponification, methylation and extraction as described previously (Kuykendall et al., 1988). The fatty acid methyl esters were separated by using a Hewlett Packard model 5890 GC equipped with a flame- 
Table 1. Thermus strains used in this study

\begin{tabular}{|c|c|c|c|}
\hline Strain & Source & Site of isolation & Reference \\
\hline \multicolumn{4}{|l|}{ T. aquaticus } \\
\hline $\mathrm{YT}^{-1^{\mathrm{T}}}\left(=\right.$ ATCC $\left.25104^{\mathrm{T}}\right)$ & ATCC & Yellowstone NP, USA & Brock \& Freeze (1969) \\
\hline YS031 & R. Sharp & Yellowstone NP, USA & Munster et al. (1986) \\
\hline \multicolumn{4}{|l|}{ T. thermophilus } \\
\hline $\mathrm{HB}^{\mathrm{T}}\left(=\mathrm{ATCC} 27634^{\mathrm{T}}\right)$ & ATCC & Mine, Japan & Oshima \& Imahori (1974) \\
\hline B (= NCIMB 11247) & R. A. D. Williams & Hruni, Iceland & Pask-Hughes \& Williams (1977) \\
\hline \multicolumn{4}{|l|}{ T. filiformis } \\
\hline Wai33.A1 ${ }^{\mathrm{T}}\left(=\right.$ ATCC $\left.43280^{\mathrm{T}}\right)$ & ATCC & Waimangu, New Zealand & Hudson et al. (1987) \\
\hline \multicolumn{4}{|l|}{ T. scotoductus } \\
\hline ITI- $252^{\mathrm{T}}\left(=\right.$ DSM $\left.8553^{\mathrm{T}}\right)$ & J. K. Kristjansson & Selfoss, Iceland & Kristjansson et al. (1994) \\
\hline X-1 (= ATCC 27978) & ATCC & Bloomington, USA & Ramaley \& Hixson (1970) \\
\hline \multicolumn{4}{|l|}{ T. brockianus } \\
\hline YS038 $\left(=\right.$ NCIMB $\left.12676^{\mathrm{T}}\right)$ & NCIMB & Yellowstone NP, USA & Williams et al. (1995) \\
\hline D13-1 & R. Sharp & Kamchatka, Russia & Unpublished \\
\hline \multicolumn{4}{|l|}{ T. oshimai } \\
\hline SPS- $17^{\mathrm{T}}\left(=\right.$ NCIMB $\left.13400^{\mathrm{T}}\right)$ & Our isolate & S. Pedro do Sul, Portugal & Williams et al. (1996) \\
\hline JK-91 & R. A. D. Williams & Hveragerdi, Iceland & Williams (1989) \\
\hline
\end{tabular}

NP, National Park.

ionization detector fitted with a $5 \%$ phenylmethyl silicone capillary column $(0.2 \mathrm{~mm} \times 25 \mathrm{~m}$; Hewlett Packard $)$. The carrier gas was high-purity $\mathrm{H}_{2}$, the column head pressure was $60 \mathrm{kPa}$, the septum purge was $5 \mathrm{ml} \mathrm{min}^{-1}$, the column split ratio was 55:1 and the injection port temperature was $300{ }^{\circ} \mathrm{C}$. The temperature of the oven was programmed from 170 to $270{ }^{\circ} \mathrm{C}$ at a rate of $5{ }^{\circ} \mathrm{C} \mathrm{min}^{-1}$. Identification and quantification of the fatty acid methyl esters and numerical analysis of the fatty acid profiles were performed by using the standard MIS Library Generation Software (Microbial ID Inc.).

Determination of mean base composition of DNA and DNA-DNA reassociation studies. The DNA used to determine DNA base compositions was isolated as described by Cashion et al. (1977). The $\mathrm{G}+\mathrm{C}$ content of the overall genome was determined by HPLC as described by Mesbah et al. (1989). DNA for DNA-DNA reassociation studies was extracted and purified by the procedure of Marmur (1961). The degree of DNA reassociation was determined spectrophotometrically from the initial renaturation rates, according to De Ley et al. (1970). The renaturation rates were measured in $1 \times \operatorname{SSC}(0 \cdot 15 \mathrm{M} \mathrm{NaCl}, 0 \cdot 015 \mathrm{M}$ trisodium citrate, $\mathrm{pH} 7 \cdot 0$ ) by using a Uvikon 940 spectrophotometer (Kontron) equipped with a thermostat-controlled cuvette chamber. The optimal renaturation temperature used in each case was calculated from the $\mathrm{G}+\mathrm{C}$ content (De Ley et al., 1970). Each hybridization experiment was executed at least twice.

16S rRNA gene sequence determination and phylogenetic analyses. The extraction of genomic DNA, PCR amplification of the 16S rRNA gene and sequencing of the purified PCR products were carried out as described previously (Rainey et al., 1996). Sequence reaction products were purified by ethanol precipitation and electrophoresed with a model 373A or a model 310 Genetic Analyzer (Applied Biosystems). The 16S rRNA sequences obtained in this study were aligned against previously determined Meiothermus/Thermus sequences available from the public databases by using the ae 2 editor (Maidak et al., 1994). The method of Jukes \& Cantor (1969) was used to calculate evolutionary distances. Phylogenetic dendrograms were generated by using various treeing algorithms contained in the PHYLIP package (De Soete, 1983; Felsenstein, 1993).

Nucleotide sequence accession numbers. The 16S rRNA gene sequences determined in this study are deposited with EMBL under the following accession numbers: Y18406 (strain RF-4 ${ }^{\mathrm{T}}$ ), Y18407 (HN1-8), Y18408 (GE-2), Y18411 (HN3-7 $)$, Y18415 (HN2-7), Y18414 (HN2-3), Y18413 (HN3-10), Y18412 (HE-5), Y18409 (T. brockianus YS038 ${ }^{\mathrm{T}}$ ), Y18410 (T. scotoductus ITI-252 ${ }^{\mathrm{T}}$ ) and Y18416 (T. oshimai SPS- $\left.17^{\mathrm{T}}\right)$. The accession numbers and strain designations of the reference 16S rRNA gene sequences used in the phylogenetic analyses are as follows: T. aquaticus YT- $1^{\mathrm{T}}$ (L09663), T. thermophilus $\mathrm{HB}^{\mathrm{T}}$ (X07998), T. filiformis Wai33.A1 ${ }^{\mathrm{T}}$ (L09667), strain ZF1.A2 (L09662) and Meiothermus ruber DSM $1279^{\mathrm{T}}$ (L09672).

\section{RESULTS}

\section{Isolation of strains, morphological and biochemical characteristics}

Strains with designations beginning with $\mathrm{HN}$ were isolated from the hot spring and run-offs at Hruni, Iceland, where the water temperature varied between 80 and $88^{\circ} \mathrm{C}$ and the $\mathrm{pH}$ was $9 \cdot 1$. Strain HE-5 was isolated from the hot spring at Hellur, Iceland, with a water temperature of $86^{\circ} \mathrm{C}$ and a $\mathrm{pH}$ of $9 \cdot 0$. Strain $\mathrm{RF}-4^{\mathrm{T}}$ was isolated from a hot spring with a water temperature of $73{ }^{\circ} \mathrm{C}$ and a $\mathrm{pH}$ of 8.9 at Reykyaflot, Iceland, and strain GE-2 was isolated from a hot spring within the Geysir geothermal area, Iceland, with a water temperature of $90^{\circ} \mathrm{C}$ and $\mathrm{pH}$ of $9 \cdot 0$.

All strains formed yellow-pigmented colonies, like most other strains of the genus Thermus, and stained 
(a)

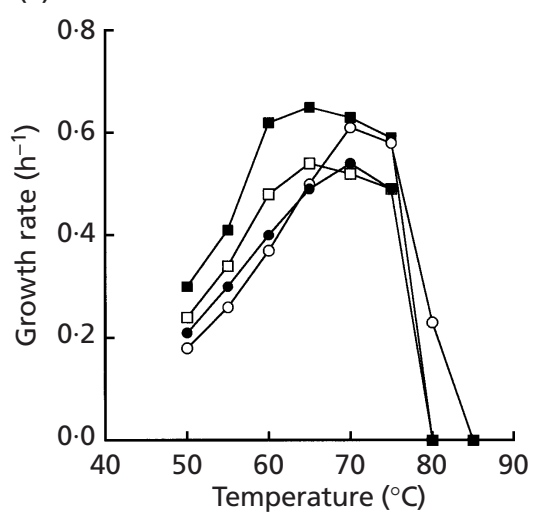

(b)

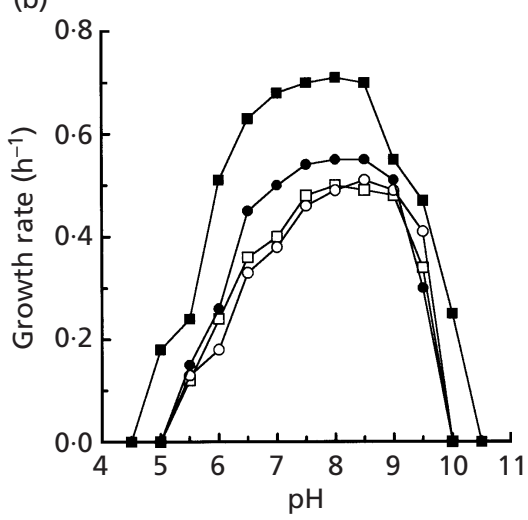

Fig. 1. Effects of temperature (a) and $\mathrm{pH}(\mathrm{b})$ on the growth of T. scotoductus ITI-252 $(0), \mathrm{HN}^{\top}-7^{\top}(\mathrm{O}), T$. brockianus $\mathrm{YSO}^{\mathrm{T}} 8^{\mathrm{T}}$

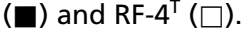

Gram-negative. Filaments and short rods were seen by phase-contrast microscopy. The strains were not motile and did not produce spores. The optimum growth temperature was about $65^{\circ} \mathrm{C}$ for strain $\mathrm{RF}-4^{\mathrm{T}}$ and about $70{ }^{\circ} \mathrm{C}$ for strain HN3-7 ${ }^{\mathrm{T}}$ (Fig. 1a). Growth did not occur at or below $45^{\circ} \mathrm{C}$. The maximum growth temperature of strains $\mathrm{HN} 3-7^{\mathrm{T}}$ and $\mathrm{HN} 2-7$ was about $80{ }^{\circ} \mathrm{C}$, while strains RF- $4^{\mathrm{T}}$ and $\mathrm{HN} 1-8$ did not grow at this temperature. Of the type and reference strains examined, only the two strains of $T$. thermophilus grew at 80 and at $82{ }^{\circ} \mathrm{C}$. Strains RF-4 ${ }^{\mathrm{T}}$ and $\mathrm{HN} 3-7^{\mathrm{T}}$ had a $\mathrm{pH}$ range of growth from about $5 \cdot 0$ or 5.5 to $9 \cdot 5$ or $10 \cdot 0$, with an optimum $\mathrm{pH}$ for growth between 7.5 and 8.5 (Fig. 1b).

The new isolates had many biochemical characteristics in common (Table 2). Nevertheless, some characteristics distinguished the two groups of strains. For example, strains RF-4 ${ }^{\mathrm{T}}$ and $\mathrm{HN} 1-8$ hydrolysed elastin but were $\alpha$-galactosidase-negative, while strains HN3$7^{\mathrm{T}}$ and HN2-7 did not hydrolyse elastin but produced $\alpha$-galactosidase. Some differences in the assimilation of single carbon sources were found among the isolates, reference strains and type strains of the species of the genus Thermus. Strains RF-4 ${ }^{\mathrm{T}}$ and HN1-8 assimilated fewer single carbon sources than all other strains examined. Moreover, only these isolates, of all the organisms examined, assimilated ribitol. The carbon-source utilization of strains HN3- $7^{\mathrm{T}}$ and HN27 closely resembled that of the other Thermus strains, the only difference being the utilization of malate as a single carbon source by these isolates.

\section{Polar lipids and fatty acid composition}

The polar lipids of the new isolates had the canonical pattern, on TLC, found in all Thermus species. One major phospholipid (PL-2) and one major glycolipid (GL-1), along with a minor glycolipid (GL-2) and phospholipid (PL-1), dominated the polar lipid fraction of these isolates (results not shown).

Branched-chain iso and anteiso fatty acids were the predominant aliphatic components of the polar lipids of all organisms examined in this study (Table 3). The fatty acid composition of strains $\mathrm{RF}-4^{\mathrm{T}}, \mathrm{HN} 1-8$ and GE-2 was characterized by very large relative proportions of iso- $15: 0$, reaching about $50 \%$ of the total, and iso-17:0, which reached levels of about $31 \%$, and by the extremely low levels of iso-16:0, which did not exceed $1 \%$ of the total acyl chains. None of the other strains examined in this or a previous study (Nobre et $a l ., 1996)$ had such high combined levels of iso-15:0 and iso-17:0 or such low levels of iso-16:0. Strains HN3-7 ${ }^{\mathrm{T}}$, HN2-7, HN2-3 and HE-5 could be distinguished from all other strains of the species of the genus Thermus by very high levels of iso-17:0 (40$50 \%)$ and relatively low levels of iso-15:0 (10-15\%). The type strain of $T$. filiformis and $T$. thermophilus strain $B$ also had low levels of iso-15:0 (4-6\%), but had very high levels of anteiso-branched fatty acids, which can easily distinguish them from all other Thermus species. It was noteworthy that the fatty acid composition of strain D13-1 had the highest relative proportion of iso-15:0 of all strains of the genus Thermus examined so far (Nobre et al., 1996).

\section{S rRNA gene sequence comparison}

Almost-complete 16S rRNA gene sequences of between 1462 and 1475 nucleotides were determined for the eight new isolates and the type strains of the species T. brockianus, T. scotoductus and T. oshimai. Phylogenetic analyses based on a dataset consisting of 1414 unambiguous nucleotides between positions 33 and 1516 (Escherichia coli positions; Brosius et al., 1978) showed the new isolates to fall into two distinct clusters within the radiation of the genus Thermus (Fig. 2). One cluster contained strains RF-4 ${ }^{\mathrm{T}}$, HN1-8 and GE-2 while strains $\mathrm{HN} 3-7^{\mathrm{T}}$, HE-5, HN3-10, HN2-3 and HN2-7 formed the second cluster (Fig. 2). The 16S rRNA gene sequence similarity values showed that, within each strain cluster, the 16S rRNA gene sequences were highly similar $(99.9 \%)$ or identical. However, only 95.9-96.2\% 16S rRNA gene sequence similarity was seen between the strains of the two clusters. Strains RF-4 ${ }^{\mathrm{T}}$, HN1-8 and GE-2 had identical 
Table 2. Biochemical characteristics that distinguish strains and species of the genus Thermus

Tests are scored as negative $(-)$, positive $(+)$ or weak $(w)$. All organisms were catalase- and cytochrome oxidase-positive; grew in medium containing $1 \% \mathrm{NaCl}$ and $0 \cdot 1 \%$ tellurite and degraded $p$-nitrophenyl $\alpha$-glucopyranoside, palmitate, laurate, hippurate, hide-powder azure and Tweens 20, 40 and 60. D-Mannose, maltose, pyruvate, L-glutamine, L-glutamate and L-proline were utilized by all strains. None of the strains hydrolysed xylan, grew in medium containing 5 or $6 \% \mathrm{NaCl}$ or utilized D-mannitol, D-sorbitol, xylitol, erythritol, L-rhamnose, L-arabinose or L-fucose.

\begin{tabular}{|c|c|c|c|c|c|c|c|c|c|c|c|c|c|c|c|}
\hline \multirow[t]{2}{*}{ Characteristic } & \multicolumn{2}{|c|}{ T. aquaticus } & \multicolumn{2}{|c|}{ T. thermophilus } & \multirow{2}{*}{$\begin{array}{l}\text { T. filiformis } \\
\text { Wai33.A1 }^{\mathrm{T}}\end{array}$} & \multicolumn{2}{|c|}{ T. scotoductus } & \multicolumn{2}{|c|}{ T. brockianus } & \multicolumn{2}{|c|}{ T. oshimai } & \multicolumn{2}{|c|}{ T. igniterrae } & \multicolumn{2}{|c|}{ T. antranikianii } \\
\hline & YT-1 ${ }^{\mathrm{T}}$ & YS031 & HB8 $^{\mathrm{T}}$ & B & & ITI-252 ${ }^{\mathrm{T}}$ & X1-t1 & $\mathrm{YSO38}^{\mathrm{T}}$ & D13-1 & SPS-17 & JK-91 & RF-4 $4^{\mathrm{T}}$ & HN1-8 & HN3-7 & HN2-7 \\
\hline Pigmentation & Yellow & Yellow & Yellow & Yellow & Yellow & White & White & Yellow & Yellow & Yellow & Yellow & Yellow & Yellow & Yellow & Yellow \\
\hline \multicolumn{16}{|l|}{ Presence of: } \\
\hline$\alpha$-Galactosidase & - & - & + & + & + & + & + & + & + & + & - & - & - & + & + \\
\hline$\beta$-Galactosidase & - & - & + & + & + & - & + & + & + & + & + & + & + & + & + \\
\hline \multicolumn{16}{|c|}{$\begin{array}{l}\text { Degradation of } p \text {-nitrophenyl } \\
\text { substrates: }\end{array}$} \\
\hline$\beta$-Glucopyranoside & + & - & + & + & + & - & + & + & + & + & + & + & + & + & + \\
\hline \multicolumn{16}{|l|}{ Degradation of: } \\
\hline Arbutin & w & $\mathrm{w}$ & + & + & + & $\mathrm{w}$ & + & + & + & + & + & + & + & + & + \\
\hline Aesculin & - & - & + & + & + & $\mathrm{w}$ & + & + & + & + & + & + & + & + & $\mathrm{w}$ \\
\hline \multicolumn{16}{|l|}{ Hydrolysis of: } \\
\hline Elastin & + & + & - & - & - & - & + & - & - & + & + & + & + & - & - \\
\hline Starch & + & + & + & + & + & + & + & - & - & + & + & + & + & + & + \\
\hline Fibrin & + & + & - & + & - & + & + & + & + & + & + & + & + & - & + \\
\hline Gelatin & + & + & + & + & + & + & + & - & + & + & + & + & + & - & + \\
\hline Casein & + & + & + & + & + & + & + & - & - & + & + & + & + & + & + \\
\hline Tween 80 & - & + & + & w & - & - & - & + & + & + & w & + & - & + & + \\
\hline Reduction of nitrate & - & - & - & + & - & + & + & + & + & + & - & + & - & + & + \\
\hline \multicolumn{16}{|l|}{ Growth at/in: } \\
\hline $80^{\circ} \mathrm{C}$ & - & - & + & + & - & - & - & - & - & - & - & - & - & + & + \\
\hline $82^{\circ} \mathrm{C}$ & - & - & + & + & - & - & - & - & - & - & - & - & - & - & - \\
\hline $2 \% \mathrm{NaCl}$ & + & - & + & + & - & - & - & - & - & $\mathrm{w}$ & + & - & - & - & - \\
\hline $3 \% \mathrm{NaCl}$ & $\mathrm{w}$ & - & + & + & - & - & - & - & - & - & - & - & - & - & - \\
\hline $4 \% \mathrm{NaCl}$ & - & - & + & + & - & - & - & - & - & - & - & - & - & - & - \\
\hline \multicolumn{16}{|l|}{ Utilization of: } \\
\hline D-Glucose & + & + & + & + & - & + & + & + & + & + & + & + & + & + & + \\
\hline D-Fructose & + & + & + & + & - & + & + & + & + & + & + & + & + & + & + \\
\hline D-Galactose & - & + & - & + & + & + & - & - & - & + & - & - & - & + & + \\
\hline L-Sorbose & - & - & - & - & - & - & + & - & - & - & $\mathrm{w}$ & - & - & - & - \\
\hline D-Xylose & - & - & + & - & - & - & - & + & + & - & - & - & - & - & - \\
\hline D-Ribose & - & - & - & - & - & - & + & - & + & - & - & - & - & - & + \\
\hline D-Cellobiose & w & + & + & + & + & - & - & + & + & - & + & - & - & + & + \\
\hline D-Melibiose & - & - & - & - & + & - & - & + & + & + & - & - & - & - & - \\
\hline D-Trehalose & + & w & + & + & + & + & - & + & + & + & + & + & - & - & - \\
\hline Sucrose & + & - & + & - & + & + & - & + & + & + & + & + & - & - & - \\
\hline Lactose & - & w & - & + & + & - & - & + & + & + & - & - & - & + & - \\
\hline D-Raffinose & - & - & - & - & + & - & - & + & + & + & - & - & - & - & - \\
\hline Glycerol & - & - & + & + & - & + & + & - & - & - & - & $\mathrm{w}$ & - & - & + \\
\hline Ribitol & - & - & - & - & - & - & - & - & - & - & - & + & + & - & - \\
\hline myo-Inositol & - & - & - & + & - & - & - & - & - & - & - & - & - & - & - \\
\hline Citrate & - & - & + & + & - & + & + & + & + & - & + & - & - & - & w \\
\hline Malate & - & - & - & - & - & w & - & - & - & - & - & - & - & + & + \\
\hline L-Asparagine & + & + & + & + & + & + & + & + & + & + & + & + & - & + & + \\
\hline L-Serine & + & + & + & + & - & + & + & + & + & - & + & - & - & + & + \\
\hline L-Arginine & + & + & - & + & - & - & + & + & + & - & + & - & - & - & + \\
\hline
\end{tabular}

16S rRNA gene sequences and shared $99 \cdot 9 \%$ sequence similarity with the previously isolated strain ZF1.A2 (Hudson et al., 1989), the 16S rRNA gene sequence of which has been described previously (Saul et al., 1993), and showed $97.3 \%$ similarity to the species $T$. brockianus and T. aquaticus. Four of the isolates of the second cluster, strains HE-5, HN3-10, HN2-3 and HN2-7, had identical 16S rRNA gene sequences and shared $99 \cdot 9 \%$ sequence similarity with strain $\mathrm{HN} 3-7^{\mathrm{T}}$. These strains showed highest 16S rRNA gene sequence similarity, $98 \cdot 0-98 \cdot 2 \%$, to the sequence of $T$. scotoductus. The $16 \mathrm{~S}$ rRNA gene sequence similarity values between the new isolates and the other validly described Thermus species, namely T. thermophilus, $T$. filiformis and T. oshimai, were in the range $92 \cdot 3-95 \cdot 4 \%$. Meiothermus ruber, which was used as the outgroup in the phylogenetic analyses (Fig. 2), showed less than $86.9 \% 16 \mathrm{~S}$ rRNA gene sequence similarity to any of the Thermus strains included.

\section{Mean base composition of DNA and DNA-DNA reassociation studies}

The $\mathrm{G}+\mathrm{C}$ content of the DNA of strains RF-4 $4^{\mathrm{T}}$ and HN3 $-7^{\mathrm{T}}$ was 70.3 and $65.4 \mathrm{~mol} \%$, respectively. The distinct species status of strains RF-4 ${ }^{\mathrm{T}}$ and HN1-8 on the one hand and strains HN3- $7^{\mathrm{T}}$, HN2-7 and HN2-3 on the other was demonstrated by values for DNADNA reassociation with the type strains and representative strains of each species of the genus Thermus 
Table 3. Fatty acid composition of Thermus strains after growth at $70^{\circ} \mathrm{C}$

Percentages of total fatty acid content are shown. Values for fatty acids present at less than $0 \cdot 5 \%$ in all strains are not shown. i, Iso; a, anteiso.

\begin{tabular}{|c|c|c|c|c|c|c|c|c|c|c|c|c|c|c|c|c|c|c|c|}
\hline Strain & $\begin{array}{l}\ddot{0} \\
\ddot{g}\end{array}$ & $\begin{array}{l}\ddot{\theta} \\
\ddot{\Xi}\end{array}$ & $\begin{array}{l}\ddot{\theta} \\
\ddot{\Xi}\end{array}$ & $\begin{array}{l}\ddot{\sigma} \\
\ddot{n}\end{array}$ & $\begin{array}{l}\stackrel{\pi}{0} \\
\ddot{n} \\
\ddot{n}\end{array}$ & $\begin{array}{l}\ddot{0} \\
\ddot{n}\end{array}$ & $\begin{array}{l}\ddot{\theta} \\
\ddot{\theta}\end{array}$ & $\stackrel{0}{\ddot{0}}$ & $\frac{\text { Oे }}{\stackrel{0}{0}}$ & 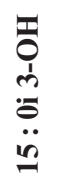 & $\begin{array}{l}\ddot{\theta} \\
\ddot{n}\end{array}$ & $\begin{array}{l}\stackrel{\pi}{\circ} \\
\ddot{x}\end{array}$ & $\begin{array}{l}\ddot{0} \\
\ddot{I}\end{array}$ & $\begin{array}{l}\tilde{0} \\
0 \\
\dot{1} \\
\ddot{0} \\
\ddot{b}\end{array}$ & 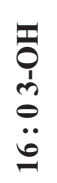 & $\begin{array}{l}\ddot{\sigma} \\
\ddot{\infty}\end{array}$ & $\begin{array}{l}\overline{0} \\
0 \\
1 \\
\ddot{0} \\
\ddot{0} \\
\ddot{n}\end{array}$ & 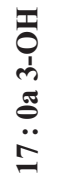 & 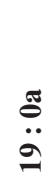 \\
\hline \multicolumn{20}{|l|}{ T. aquaticus } \\
\hline $\mathrm{YT}^{\mathrm{T}} 1^{\mathrm{T}}$ & - & $1 \cdot 0$ & $1 \cdot 4$ & $19 \cdot 3$ & $2 \cdot 1$ & - & $13 \cdot 4$ & $16 \cdot 2$ & - & $3 \cdot 2$ & $24 \cdot 9$ & $2 \cdot 6$ & - & $2 \cdot 6$ & $2 \cdot 3$ & $0 \cdot 6$ & $7 \cdot 6$ & $0 \cdot 8$ & - \\
\hline YS031 & - & - & - & $22 \cdot 0$ & $1 \cdot 6$ & - & $9 \cdot 8$ & $7 \cdot 9$ & - & $3 \cdot 1$ & $38 \cdot 7$ & $2 \cdot 9$ & - & $1 \cdot 6$ & - & - & $10 \cdot 0$ & $0 \cdot 6$ & - \\
\hline \multicolumn{20}{|l|}{ T. thermophilus } \\
\hline $\mathrm{HB} 8^{\mathrm{T}}$ & - & $0 \cdot 7$ & - & $32 \cdot 4$ & $4 \cdot 3$ & - & $5 \cdot 3$ & $10 \cdot 0$ & $0 \cdot 7$ & - & $41 \cdot 4$ & $5 \cdot 1$ & - & - & - & - & - & - & - \\
\hline $\mathrm{B}$ & - & $0 \cdot 8$ & - & $5 \cdot 5$ & $8 \cdot 2$ & - & $13 \cdot 9$ & $6 \cdot 6$ & $1 \cdot 9$ & - & $25 \cdot 03$ & $31 \cdot 1$ & - & - & - & $3 \cdot 4$ & - & - & $1 \cdot 6$ \\
\hline \multicolumn{20}{|l|}{ T. filiformis } \\
\hline Wai33.A1 ${ }^{\mathrm{T}}$ & - & $0 \cdot 9$ & - & $4 \cdot 0$ & $17 \cdot 9$ & - & $8 \cdot 7$ & $4 \cdot 1$ & $4 \cdot 0$ & - & $6 \cdot 33$ & $35 \cdot 5$ & - & 0.9 & - & $1 \cdot 0$ & $2 \cdot 3$ & $8 \cdot 6$ & $1 \cdot 0$ \\
\hline \multicolumn{20}{|l|}{ T. scotoductus } \\
\hline ITI-252 & - & - & - & $17 \cdot 9$ & $13 \cdot 8$ & $1 \cdot 0$ & $1 \cdot 6$ & $8 \cdot 6$ & $2 \cdot 4$ & - & $30 \cdot 32$ & $22 \cdot 1$ & $1 \cdot 3$ & - & - & - & - & - & $0 \cdot 6$ \\
\hline X1-t1 & - & $1 \cdot 7$ & - & $19 \cdot 5$ & $4 \cdot 5$ & $0 \cdot 9$ & $23 \cdot 7$ & $8 \cdot 7$ & - & - & $30 \cdot 0$ & $6 \cdot 7$ & - & - & - & $2 \cdot 3$ & - & - & - \\
\hline \multicolumn{20}{|l|}{ T. brockianus } \\
\hline YS038 & $0 \cdot 7$ & $1 \cdot 3$ & $0 \cdot 7$ & $31 \cdot 8$ & $2 \cdot 5$ & $0 \cdot 8$ & $11 \cdot 0$ & $12 \cdot 3$ & - & - & $35 \cdot 2$ & $2 \cdot 8$ & - & - & - & $0 \cdot 6$ & - & - & - \\
\hline D13-1 & $0 \cdot 6$ & $1 \cdot 1$ & $1 \cdot 0$ & $58 \cdot 6$ & $4 \cdot 8$ & $1 \cdot 1$ & $6 \cdot 7$ & $9 \cdot 5$ & $1 \cdot 1$ & - & $12 \cdot 3$ & $3 \cdot 1$ & - & - & - & - & - & - & - \\
\hline \multicolumn{20}{|l|}{ T. oshimai } \\
\hline SPS- $17^{\mathrm{T}}$ & $0 \cdot 7$ & - & - & $36 \cdot 2$ & $2 \cdot 9$ & $3 \cdot 1$ & $2 \cdot 5$ & $8 \cdot 8$ & - & - & $38 \cdot 3$ & $3 \cdot 2$ & $2 \cdot 1$ & - & - & - & - & - & - \\
\hline JK-91 & $0 \cdot 9$ & - & - & $40 \cdot 2$ & $2 \cdot 9$ & $1 \cdot 6$ & $2 \cdot 8$ & $10 \cdot 5$ & - & - & $35 \cdot 6$ & $3 \cdot 1$ & $0 \cdot 8$ & - & - & - & - & - & - \\
\hline \multicolumn{20}{|l|}{ T. igniterrae } \\
\hline $\mathrm{RF}-4^{\mathrm{T}}$ & $1 \cdot 1$ & - & - & $50 \cdot 7$ & $2 \cdot 9$ & $1 \cdot 3$ & $1 \cdot 0$ & $9 \cdot 0$ & - & - & $31 \cdot 1$ & 1.9 & - & - & - & - & - & - & - \\
\hline HN1-8 & 1.9 & - & - & $49 \cdot 4$ & $2 \cdot 5$ & $1 \cdot 7$ & 0.9 & $8 \cdot 9$ & - & - & $31 \cdot 9$ & $1 \cdot 5$ & $1 \cdot 0$ & - & - & - & - & - & - \\
\hline GE-2 & $1 \cdot 0$ & - & - & $49 \cdot 5$ & $2 \cdot 7$ & $2 \cdot 2$ & $1 \cdot 4$ & $8 \cdot 9$ & - & - & $30 \cdot 2$ & $1 \cdot 8$ & $0 \cdot 8$ & - & - & - & - & - & - \\
\hline \multicolumn{20}{|l|}{ T. antranikianii } \\
\hline $\mathrm{HN} 3-7^{\mathrm{T}}$ & - & - & - & $10 \cdot 8$ & $1 \cdot 7$ & $1 \cdot 9$ & $9 \cdot 6$ & $11 \cdot 9$ & - & - & $51 \cdot 0$ & $6 \cdot 2$ & $3 \cdot 1$ & - & - & $1 \cdot 4$ & - & - & - \\
\hline HN2-7 & - & $0 \cdot 7$ & - & $13 \cdot 8$ & $2 \cdot 5$ & $0 \cdot 8$ & $18 \cdot 9$ & $10 \cdot 0$ & $0 \cdot 6$ & - & $43 \cdot 1$ & $6 \cdot 0$ & 0.6 & - & - & $1 \cdot 4$ & - & - & - \\
\hline HN2-3 & $0 \cdot 6$ & $0 \cdot 7$ & - & $14 \cdot 9$ & $2 \cdot 9$ & $0 \cdot 8$ & $17 \cdot 6$ & $11 \cdot 0$ & $0 \cdot 8$ & - & $40 \cdot 4$ & $7 \cdot 1$ & - & - & - & $1 \cdot 3$ & - & - & - \\
\hline HE-5 & - & - & - & $12 \cdot 7$ & $1 \cdot 8$ & $2 \cdot 7$ & $8 \cdot 8$ & $12 \cdot 2$ & $0 \cdot 8$ & - & $49 \cdot 0$ & $5 \cdot 6$ & $4 \cdot 4$ & - & - & $1 \cdot 1$ & - & - & - \\
\hline
\end{tabular}

*Unknown fatty acid or alcohol with an equivalent chain-length (ECL) of 16.090.

(Table 4). The DNA-DNA reassociation values of strain RF-4 $4^{\mathrm{T}}$ were low with all strains except strain HN1-8, while strains HN3-7 ${ }^{\mathrm{T}}$, HN2-7 and HN2-3 had the highest DNA-DNA reassociation values with each other, in the range 86-91\%. Strain D13-1 from the Kamchatka Peninsula was also shown to have a very high DNA-DNA reassociation value $(83 \%)$ with the type strain of $T$. brockianus from Yellowstone National Park.

\section{DISCUSSION}

Biochemical and physiological characteristics are not generally useful for distinguishing species of the genus Thermus from each other. In fact, most species cannot be distinguished from each other on the basis of these characteristics and their description has been based, almost entirely, on DNA-DNA reassociation values (Williams et al., 1995, 1996).
Fatty acid analysis has been used successfully in the description and identification of many species of bacteria, but it is too difficult to use in distinguishing the species of this genus. The strains assigned to the species $T$. thermophilus, for example, have variable fatty acid compositions even though some strains originate from hot springs in the same general area; strains HB8, HB27, AT-62 and GK-24 from Japan are notorious in this respect (Nobre et al., 1996). It should also be noted that strain D13-1 from the Kamchatka Peninsula belongs to T. brockianus because of the high DNA-DNA reassociation value with the type strain and the very similar biochemical and physiological characteristics. However, the fatty acid composition of strain D13-1 is radically different from all isolates of this species from Yellowstone National Park. The large diversity of phenotypic characteristics within each species is difficult to explain. However, extensive DNA-DNA reassociation studies and 16S rRNA gene 


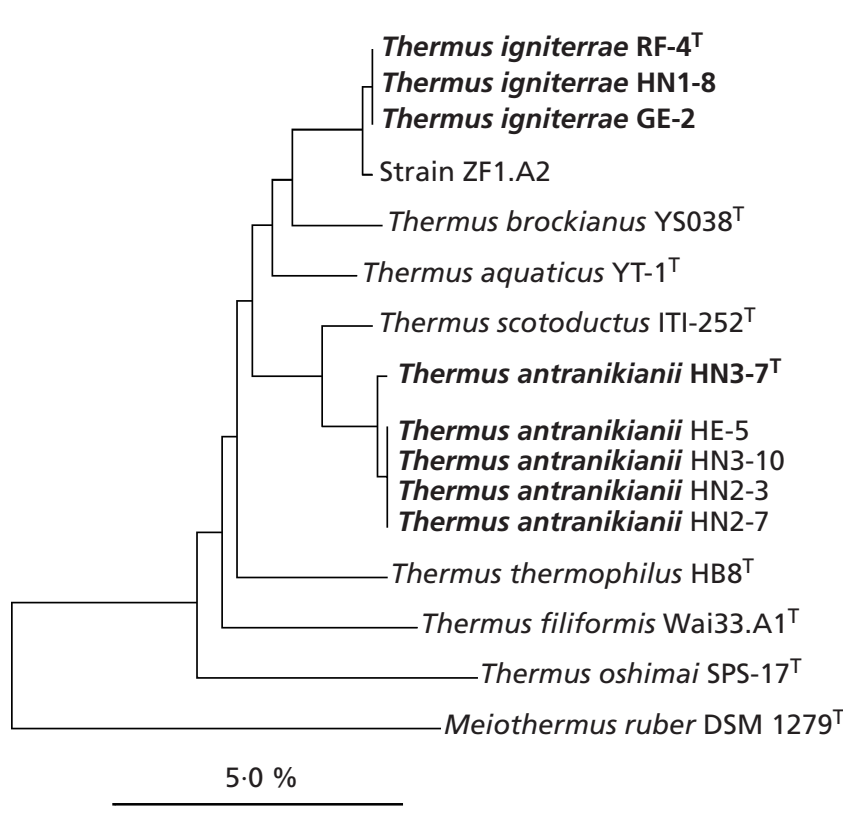

Fig. 2. Phylogenetic dendrogram based on $16 \mathrm{~S}$ rRNA gene sequence comparisons. The dendrogram was reconstructed from evolutionary distances by using the neighbour-joining method. The scale bar represents five inferred nucleotide changes per 100 nucleotides.

sequence analyses indicate that the species of the genus Thermus are composed of closely related strains that are, nevertheless, phenotypically variable (Saul et al., 1993 ; A. P. Chung, M. F. Nobre, M. S. da Costa \& F. A. Rainey, unpublished results).

The description of species of the genus Thermus should include isolates from several geographical areas, but this has not generally been the case because isolates of new species are sometimes limited to one geographical area; T. aquaticus and $T$. filiformis, for example, have only been isolated from Yellowstone National Park and from New Zealand, respectively. The same is true for the isolates described in this study, which we propose represent two new species of the genus Thermus. Physiological, biochemical and tolerance characteristics do not distinguish the two groups of Icelandic strains clearly from the other species of the genus Thermus, although the species represented by strains $\mathrm{HN} 3-7^{\mathrm{T}}$ and $\mathrm{HN} 2-7$ grows at $80{ }^{\circ} \mathrm{C}$. This is a very rare characteristic among species of the genus Thermus, only being present in strains of $T$. thermophilus, which can also grow at $82{ }^{\circ} \mathrm{C}$. However, the fatty acid composition of isolates representing these two new species of the genus Thermus is, at present, fairly homogeneous and distinguishes these two groups of strains from each other and from all the other strains of this genus (Nobre et al., 1996). Strains RF$4^{\mathrm{T}}$, HN1-8 and GE-2 have the highest combined levels of iso-15:0 and iso-17:0 and the lowest levels of iso16:0 of any strain of the species of the genus Thermus examined so far. On the other hand, strains HN3 $-7^{\mathrm{T}}$, HN2-7, HN2-3 and HE-5 can be distinguished from all other strains of the species of the genus Thermus by the very low iso-15:0/iso-17:0 ratio.

All the isolates of the two new species of Thermus originated from Iceland, but were recovered from different hot springs, indicating that the organisms are widespread and may not represent a single clone. Phylogenetic analyses show that these isolates represent two distinct lineages within the Thermus species group. Strains RF-4 ${ }^{\mathrm{T}}, \mathrm{HN} 1-8$ and GE-2 are most closely related to $T$. brockianus and T. aquaticus, while strains HN3-7 ${ }^{\mathrm{T}}$, HN2-7, HN2-3, HN3-10 and HE-5 are most closely related to T. scotoductus. Although these new isolates show more than $97 \%$ 16S rRNA gene sequence similarity to previously described Thermus species, the results of DNA-DNA reassociation studies show that the isolates represent two new species of the genus Thermus. On the basis of these

Table 4. DNA-DNA reassociation values between Thermus strains

Values are means of at least two determinations. -, Not determined.

\begin{tabular}{|c|c|c|c|c|c|c|c|c|c|c|c|c|c|}
\hline Strain & 1 & 2 & 3 & 4 & 5 & 6 & 7 & 8 & 9 & 10 & 11 & 12 & 13 \\
\hline 1. T. aquaticus $\mathrm{YT}-1^{\mathrm{T}}$ & 100 & & & & & & & & & & & & \\
\hline 2. T. thermophilus $\mathrm{HB}^{\mathrm{T}}$ & 35 & 100 & & & & & & & & & & & \\
\hline 3. T. filiformis Wai33.A $1^{\mathrm{T}}$ & - & - & 100 & & & & & & & & & & \\
\hline 4. T. scotoductus ITI-252 & 19 & 30 & 26 & 100 & & & & & & & & & \\
\hline 5. T. scotoductus X1-t1 & 55 & - & - & 79 & 100 & & & & & & & & \\
\hline 6. T. brockianus $\mathrm{YS} 038^{\mathrm{T}}$ & - & - & - & - & - & 100 & & & & & & & \\
\hline 7. T. brockianus D13-1 & - & - & - & - & 41 & 83 & 100 & & & & & & \\
\hline 8. T. oshimai SPS- $17^{\mathrm{T}}$ & 47 & 34 & - & 27 & - & - & 36 & 100 & & & & & \\
\hline 9. T. igniterrae $\mathrm{RF}-4^{\mathrm{T}}$ & 38 & 57 & 32 & 34 & 59 & 34 & 40 & 39 & 100 & & & & \\
\hline 10. T. igniterrae $\mathrm{HN} 1-8$ & - & - & - & - & - & 20 & 32 & - & 83 & 100 & & & \\
\hline 11. T. antranikianii $\mathrm{HN} 3-7^{\mathrm{T}}$ & 35 & 24 & 28 & 56 & 58 & 41 & 32 & 39 & 40 & - & 100 & & \\
\hline 12. T. antranikianii HN2-7 & - & - & - & 55 & 54 & - & - & - & - & - & 91 & 100 & \\
\hline 13. T. antranikianii $\mathrm{HN} 2-3$ & - & - & - & 41 & 50 & - & - & - & - & - & 86 & 94 & 100 \\
\hline
\end{tabular}


findings, we propose that strains $\mathrm{RF}-4^{\mathrm{T}}$ and $\mathrm{HN} 1-8$ represent a new species of the genus Thermus, for which we propose the name Thermus igniterrae sp. nov., and that strains HN3-7 ${ }^{\mathrm{T}}$ and HN2-7 represent another novel species of this genus, for which we propose the name Thermus antranikianii sp. nov.

\section{Description of Thermus igniterrae sp. nov.}

Thermus igniterrae (ig.ni.ter'rae. L. n. ignis fire; L. fem. n. terra land/earth; M. L. gen. fem. n. igniterrae of the land of fire, referring to Iceland).

T. igniterrae strains form rod-shaped cells of variable length that are $0 \cdot 5-0 \cdot 8 \mu \mathrm{m}$ wide. Filaments are also present. Gram stain is negative. The cells are nonmotile and spores are not formed. Colonies on Thermus medium are yellow-pigmented and 1-2 mm in diameter after $72 \mathrm{~h}$ growth. Growth occurs above $45^{\circ} \mathrm{C}$ and below $80^{\circ} \mathrm{C}$; the optimum growth temperature for strain $\mathrm{RF}-4^{\mathrm{T}}$ is about $65^{\circ} \mathrm{C}$. The optimum $\mathrm{pH}$ is between 7.5 and 8.5; growth does not occur at $\mathrm{pH} 5.0$ or $\mathrm{pH} 10 \cdot 0$. The major fatty acids are $15: 0$ iso and 17:0 iso; $3-\mathrm{OH}$ fatty acids are not present. All strains are oxidase-positive and catalase-positive. Strain $\mathrm{RF}-4^{\mathrm{T}}$ reduces nitrate to nitrite, while strain HN1-8 does not; $\alpha$-galactosidase is negative and $\beta$ galactosidase is positive. Elastin, starch, fibrin, casein, gelatin and hide-powder azure are hydrolysed. Arbutin and aesculin are degraded. Strains RF-4 ${ }^{\mathrm{T}}$ and HN1-8 utilize D-glucose, D-fructose, D-mannose, maltose, ribitol, pyruvate, L-glutamate, L-glutamine and Lproline. Strains RF-4 ${ }^{\mathrm{T}}$ and HN1-8 do not utilize D-galactose, D-melibiose, D-cellobiose, D-raffinose, Dxylose, D-ribose, lactose, D-mannitol, D-sorbitol, xylitol, erythritol, glycerol, malate, citrate, myo-inositol, L-sorbose, L-fucose, L-arabinose, L-rhamnose, L-serine or L-arginine.

The DNA of strain $\mathrm{RF}-4^{\mathrm{T}}$ has a $\mathrm{G}+\mathrm{C}$ content of $70 \cdot 3 \mathrm{~mol} \%$. This bacterium was isolated from hot springs at Reykyaflot in Iceland. Strain RF-4 ${ }^{\mathrm{T}}$ has been deposited in the DSMZ as strain DSM $12459^{\mathrm{T}}$. Strain HN1-8 (DSM 12460) is an additional strain of this species.

\section{Description of Thermus antranikianii sp. nov.}

Thermus antranikianii (an.tra.ni.ki.a'ni.i. M.L. adj. antranikianii in honour of Garabed Antranikian, for his contribution to our knowledge of thermophilic and hyperthermophilic organisms).

$T$. antranikianii strains form rod-shaped cells of variable length that are $0.5-0.8 \mu \mathrm{m}$ wide. Filaments are also present. Gram stain is negative. The cells are nonmotile and spores are not formed. Colonies on Thermus medium are yellow-pigmented and 1-2 mm in diameter after $72 \mathrm{~h}$ growth. Growth occurs above $50{ }^{\circ} \mathrm{C}$ and at $80^{\circ} \mathrm{C}$; the optimum growth temperature for strain $\mathrm{HN} 3-7^{\mathrm{T}}$ is about $70{ }^{\circ} \mathrm{C}$. The optimum $\mathrm{pH}$ is between 7.5 and 8.5 ; growth does not occur at $\mathrm{pH} 4.5$ or $\mathrm{pH} 10 \cdot 5$. The major fatty acids are 17:0 iso, 16:0 iso and 15:0 iso; $3-\mathrm{OH}$ fatty acids are not present. All strains are oxidase-positive and catalase-positive. Nitrate is reduced to nitrite. $\alpha$ - and $\beta$-galactosidasepositive. Starch, casein, hide-powder azure and Tween 80 are hydrolysed. Degradation of arbutin and aesculin is positive. Strains HN3-7 ${ }^{\mathrm{T}}$ and HN2-7 do not hydrolyse elastin. Strains HN3-7 ${ }^{\mathrm{T}}$ and HN2-7 utilize Dglucose, D-fructose, D-mannose, D-galactose, D-cellobiose, maltose, pyruvate, malate, L-glutamate, L-asparagine, L-glutamine, L-serine and L-proline. Strains HN3-7 ${ }^{\mathrm{T}}$ and HN2-7 do not utilize D-xylose, D-melibiose, D-trehalose, D-raffinose, sucrose, Dmannitol, D-sorbitol, ribitol, xylitol, erythritol, myoinositol, L-sorbose, L-arabinose, L-rhamnose or L-fucose.

The DNA of strain HN3- $7^{\mathrm{T}}$ has a $\mathrm{G}+\mathrm{C}$ content of $65.4 \mathrm{~mol} \%$. This bacterium was isolated from hot springs at Hruni in Iceland. Strain HN3-7 $7^{\mathrm{T}}$ has been deposited in the DSMZ as strain DSM $12462^{\mathrm{T}}$. Strain HN2-7 (DSM 12461) is an additional strain of this species.

\section{ACKNOWLEDGEMENTS}

This work was supported, in part, by the European Community Biotech Programme (Biotechnology of Extremophiles) contract no. BIO2-CT93-0274 and by the PRAXIS XXI Programme (PRAXIS 2/2.1/BIO/20/94), Portugal. A.P.C. was supported by a PRAXIS XXI scholarship (PRAXIS XXI/BD/3907/94). We also thank Hans Trüper (Bonn, Germany) for his advice in naming the organisms.

\section{REFERENCES}

Brock, T. D. \& Boylen, K. L. (1969). Presence of thermophilic bacteria in laundry and domestic hot-water heaters. Appl Microbiol 25, 72-76.

Brock, T. D. \& Freeze, H. (1969). Thermus aquaticus gen. n. and sp. n., a nonsporulating extreme thermophile. J Bacteriol $\mathbf{9 8}$, 289-297.

Brosius, J., Palmer, M. L., Kennedy, P. J. \& Noller, H. F. (1978). Complete nucleotide sequence of a $16 \mathrm{~S}$ ribosomal RNA gene from Escherichia coli. Proc Natl Acad Sci USA 75, 4801-4805.

Cashion, P., Holder-Franklin, M. A., McCully, J. \& Franklin, M. (1977). A rapid method for the base ratio determination of bacterial DNA. Anal Biochem 81, 461-466.

De Ley, J., Cattoir, H. \& Reynaerts, A. (1970). The quantitative measurement of DNA hybridization from renaturation rates. Eur J Biochem 12, 133-142.

De Soete, G. (1983). A least squares algorithm for fitting additive trees to proximity data. Psychometrika 48, 621-626.

Degryse, E., Glansdorff, N. \& Pierard, A. (1978). A comparative analysis of extreme thermophilic bacteria belonging to the genus Thermus. Arch Microbiol 117, 189-196.

Donato, M. M., Seleiro, E. A. \& da Costa, M. S. (1990). Polar lipid and fatty acid composition of strains of the genus Thermus. Syst Appl Microbiol 13, 234-239. 
Felsenstein, J. (1993). PHYLIP (phylogenetic inference package) version 3.5.1. Department of Genetics, University of Washington, Seattle, WA, USA.

Ferraz, A. S., Carreto, L., Tenreiro, S., Nobre, M. F. \& da Costa, M. S. (1994). Polar lipids and fatty acid composition of Thermus strains from New Zealand. Antoine Leeuwenhoek 66, 357-363.

Georganta, G., Smith, K. E. \& Williams, R. A. D. (1993). DNADNA homology and cellular components of Thermus filiformis and other strains of Thermus from New Zealand hot springs. FEMS Microbiol Lett 107, 145-150.

Hudson, J. A., Morgan, H. W. \& Daniel, R. M. (1987). Thermus filiformis sp. nov., a filamentous caldoactive bacterium. Int $J$ Syst Bacteriol 37, 431-436.

Hudson, J. A., Morgan, H. W. \& Daniel, R. M. (1989). Numerical classification of Thermus isolates from globally distributed hot springs. Syst Appl Microbiol 11, 250-256.

Jukes, T. H. \& Cantor, C. R. (1969). Evolution of protein molecules. In Mammalian Protein Metabolism, pp. 21-132. Edited by H. N. Munro. New York: Academic Press.

Kristjansson, J. K. \& Alfredsson, G. A. (1983). Distribution of Thermus spp. in Icelandic hot springs and a thermal gradient. Appl Environ Microbiol 45, 1785-1789.

Kristjansson, J. K., Hjörleifsdottir, S., Marteinsson, V. T. \& Alfredsson, G. A. (1994). Thermus scotoductus, sp. nov., a pigment-producing thermophilic bacterium from hot tap water in Iceland and including Thermus sp. X-1. Syst Appl Microbiol 17, 44-50.

Kuykendall, L. D., Roy, M. A., O’Neill, J. J. \& Devine, T. E. (1988). Fatty acids, antibiotic resistance, and deoxyribonucleic acid homology groups of Bradyrhizobium japonicum. Int J Syst Bacteriol 38, 358-361.

Maidak, B. L., Larsen, N., McCaughey, M. J., Overbeek, R., Olsen, G. J., Fogel, K., Blandy, J. \& Woese, C. R. (1994). The Ribosomal Database Project. Nucleic Acids Res 22, 3485-3487.

Manaia, C. M. \& da Costa, M. S. (1991). Characterization of halotolerant Thermus isolates from shallow marine hot springs on S. Miguel, Azores. J Gen Microbiol 137, 2643-2648.

Manaia, C. M., Hoste, B., Gutierrez, M. C., Gillis, M., Ventosa, A., Kersters, K. \& da Costa, M. S. (1994). Halotolerant Thermus strains from marine and terrestrial hot springs belong to Thermus thermophilus (ex Oshima and Imahori, 1974) nom. rev. emend. Syst Appl Microbiol 17, 526-532.

Marmur, J. (1961). A procedure for the isolation of deoxyribonucleic acid from microorganisms. J Mol Biol 3, 208-218.

Marteinsson, V. T., Birrien, J. L., Kristjansson, J. K. \& Prieur, D. (1995). First isolation of thermophilic aerobic nonsporulating heterotrophic bacteria from deep-sea hydrothermal vents. FEMS Microbiol Ecol 18, 163-174.

Mesbah, M., Premachandran, U. \& Whitman, W. B. (1989). Precise measurement of the $\mathrm{G}+\mathrm{C}$ content of deoxyribonucleic acid by high-performance liquid chromatography. Int J Syst Bacteriol 39, 159-167.

Munster, M. J., Munster, A. P., Woodrow, J. R. \& Sharp, R. J. (1986). Isolation and preliminary taxonomic studies of Thermus strains isolated from Yellowstone National Park, USA. J Gen Microbiol 132, 1677-1683.
Nobre, M. F., Carreto, L., Wait, R., Tenreiro, S., Fernandes, O., Sharp, R. J. \& da Costa, M. S. (1996). Fatty acid composition of the species of the genera Thermus and Meiothermus. Syst Appl Microbiol 19, 303-311.

Oshima, T. \& Imahori, K. (1974). Description of Thermus thermophilus (Yoshida and Oshima) comb. nov., a nonsporulating thermophilic bacterium from a Japanese thermal spa. Int J Syst Bacteriol 24, 102-112.

Pask-Hughes, R. A. \& Williams, R. A. D. (1977). Yellow-pigmented strains of Thermus spp. from Icelandic hot springs. $J$ Gen Microbiol 102, 375-383.

Prado, A., da Costa, M. S. \& Madeira, V. M. C. (1988). Effect of growth temperature on the lipid composition of two strains of Thermus sp. J Gen Microbiol 134, 1653-1660.

Rainey, F. A., Ward-Rainey, N., Kroppenstedt, R. M. \& Stackebrandt, E. (1996). The genus Nocardiopsis represents a phylogenetically coherent taxon and a distinct actinomycete lineage: proposal of Nocardiopsaceae fam. nov. Int $J$ Syst Bacteriol 46, 1088-1092.

Ramaley, R. F. \& Hixson, J. (1970). Isolation of a nonpigmented, thermophilic bacterium similar to Thermus aquaticus. J Bacteriol 103, 526-528.

Santos, M. A., Williams, R. A. D. \& da Costa, M. S. (1989). Numerical taxonomy of Thermus isolates from hot springs in Portugal. Syst Appl Microbiol 12, 310-315.

Saul, D. J., Rodrigo, A. G., Reeves, R. A., Williams, L. C., Borges, K. M., Morgan, H. W. \& Bergquist, P. L. (1993). Phylogeny of twenty Thermus isolates constructed from 16S rRNA gene sequence data. Int J Syst Bacteriol 43, 754-760.

Tenreiro, S., Nobre, M. F., Hoste, B., Gillis, M., Kristjansson, J. K. \& da Costa, M. S. (1995). DNA-DNA hybridization and chemotaxonomic studies of Thermus scotoductus. Res Microbiol 146, 315-324.

Wait, R., Carreto, L., Nobre, M. F., Ferreira, A. M. \& da Costa, M. S. (1997). Characterization of novel long-chain 1,2-diols in Thermus species and demonstration that Thermus strains contain both glycerol-linked and diol-linked glycolipids. J Bacteriol 179, 6154-6162.

Williams, R. A. D. (1989). Biochemical taxonomy of the genus Thermus. In Microbiology of Extreme Environments and its Potential for Biotechnology, pp. 82-97. Edited by M. S. da Costa, J. C. Duarte \& R. A. D. Williams. London: Elsevier.

Williams, R. A. D. \& da Costa, M. S. (1992). The genus Thermus and related microorganisms. In The Prokaryotes, 2nd edn, pp. 3745-3753. Edited by A. Balows, H. G. Trüper, M. Dworkin, W. Harder \& K.-H. Schleifer. New York: Springer.

Williams, R. A. D., Smith, K. E., Welch, S. G., Micallef, J. \& Sharp, R. J. (1995). DNA relatedness of Thermus strains, description of Thermus brockianus sp. nov., and proposal to reestablish Thermus thermophilus (Oshima and Imahori). Int $J$ Syst Bacteriol 45, 495-499.

Williams, R. A. D., Smith, K. E., Welch, S. G. \& Micallef, J. (1996). Thermus oshimai sp. nov., isolated from hot springs in Portugal, Iceland and the Azores, and comment on the concept of a limited geographical distribution of Thermus species. Int $J$ Syst Bacteriol 46, 403-408. 